\title{
Kajian Pustaka: Sumber Reactive Oxygen Species (ROS) Vaskular
}

\author{
(Review: Vascular sources of Reactive Oxygen Species)
}

I Dewa Ayu Susilawati

Department of Biomedical Science, Faculty of Dentistry, Universitas Jember, Indonesia

\begin{abstract}
Abstrak
Peningkatan produksi ROS vaskuler berperan penting pada patogenesis hampir setiap tahap penyakit kardiovaskuler (PJK), seperti aterosklerosis, hipertensi, infark miokardial akut dan lain-lain. Tulisan ini menyajikan ulasan singkat sumber-sumber ROS vaskuler. ROS vaskuler terutama berasal dari sumber-sumber enzimatik pada sel-sel vaskuler fagositik seperti netrofil, monosit dan makrofag, juga dari sel-sel nonfagositik seperti endotelium, SMC dan fibroblas. Sumber ROS vaskuler meliputi, NADPH oksidase, xantin oksidase, eNOS, lipoksigenase, siklooksigenase dan sistem transpor elektron mitokondrial. Kesimpulannya, produksi ROS yang berlebihan akan memicu kondisi stres oksidatif yang membahayakan kesehatan kardiovaskuler. Pemahaman yang lebih baik tentang ROS vaskuler dapat bermanfaat untuk pengembangan metode pencegahan PJK berbasis inhibisi ROS
\end{abstract}

Kata Kunci: Aterosklerosis, Makrofag, Monosit, Mitokondria, Netrofil

\section{Abstract}

Increasing amount of vascular reactive oxygen species (ROS) play a key role in the pathogenesis of almost all stages of cardiovascular diseases (CVD), such as atherosclerosis, hypertension, myocardial infartion, etc. This paper aimed to present a brief review of the important vascular sources of ROS. Vascular ROS is mainly produced by enzymatic sources in the vascular cells, i.e. phagocytic inflammatory cells (neutrophils, monocytes/macrophages), and nonphagocytic cells (endothelium, smooth muscle cell and fibroblast). Enzymatic sources of vascular ROS are NADPH oxidase, xanthine oxidase, eNOS, lipoxygenase, cyclooxygenase, and mitochondrial electron transport. In conclusion, over production of ROS induce oxidative burst and will be detrimental for cardiovascular health. A better understanding of ROS would be worwhile for developing method for preventing CVD based on ROS inhibition.

Key words: Atherosclerosis, Macrophage, Monocyte, Mitochondria, Neutrophil

Korespondensi (Correspondence) : I Dewa Ayu Susilawati, Fakultas Kedokteran Gigi Universitas Jember, Jl. Kalimantan 37 Jember, Email: dewasusi@unej.ac.id

Reactive oxygen species normalnya terdapat dalam jumlah kecil di dalam sel dan berperan pada proses signaling dan homeostasis.' Keseimbangan antara siklus pembentukan dan inaktivasi ROS dipertahankan oleh sistem enzimatik dan non enzimatik endogenus. Produksi ROS yang berlebihan bila tidak diimbangi dengan sistem antioksidan yang memadai menyebabkan terjadinya keadaan prooksidatif yang mengarah ke kondisi stres oksidatif, yang berperan pada patogenesis berbagai penyakit. 1,2

Adanya ROS pada material biologis ditemukan kira-kira 70 tahun yang lalu. Segera setelah itu Denham Harman membuat hipotesis bahwa radikal oksigen dibentuk sebagai produk samping dari reaksi enzimatis in vivo. Pada tahun 1956, la menggambarkan radikal bebas sebagai :"a Pandora's box of evils" ("kotak pandora") yang dapat menyebabkan kerusakan, mutagenesis, kanker dan degenerasi pada penuaan. ${ }^{3}$

Pengetahuan tentang ROS pada organisme hidup memasuki era kedua setelah McCord dan Fridovich pada tahun 1969 menemukan enzim superoksid dismutase (SOD), dan akhirnya mereka menyakinkan banyak orang bahwa ROS berperan penting dalam proses biologik. Banyak peneliti kemudian terinspirasi untuk meneliti kerusakan oksidatif yang disebabkan ROS pada molekul
DNA, protein, lipid, dan komponen lain pada sel. ${ }^{3}$

Berbagai bukti telah menunjukkan bahwa sel-sel vaskuler dapat memproduksi ROS dan meningkatnya produksi ROS baik secara kronis maupun akut, berhubungan dengan berbagai gangguan kardiovaskuler seperti aterosklerosis, hipertensi, angina pektoris, dan congesive heart failure. Pada kasus-kasus fatal seperti infark miokardial akut dan sudden death, produksi ROS juga berperan. Data biokemis, fisiologis dan farmakologis mendukung hubungan peningkatan ROS dengan patogenesis berbagai penyakit kardiovaskuler. $4,5,6,7$

ROS diketahui dapat memodulasi fungsi vaskuler, baik dengan menyebabkan kerusakan secara langsung, ataupun dengan mengaktifkan jalur signaling yang menyebabkan abnormalitas vaskuler. ${ }^{8}$ Penelitian-penelitian pada sel dan hewan coba menunjukkan bahwa ROS memediasi atau meningkatkan pada hampir setiap aspek pembentukan lesi aterosklerotik. Salah satu proses yang telah dikenal adalah peran ROS pada modifikasi oksidatif low-density lipoprotein (LDL), atau modifikasi enzimatik secara langsung melalui lipoksigenesis. ROS juga diketahui terlibat pada inflamasi, mempengaruhi vasomotor, menginduksi apoptosis, menyebabkan agregasi platelet dan menstimulasi proliferasi SMC vaskuler. ${ }^{9}$ ROS dapat mengaktifkan matrix 
metalloproteinases (MMPs) yang berperan penting pada ruptur plak aterosklerotik. 10 Fakta-fakta tersebut menekankan pentingnya pemahaman pembentukan dan sumber ROS vaskuler.

\section{KAJIAN PUSTAKA}

\section{Metabolisme ROS}

Istilah ROS merujuk pada sekumpulan metabolit yang berasal dari molekul oksigen $\left(\mathrm{O}_{2}\right)$. ROS merupakan senyawa antara metabolisme oksigen yang sangat reaktif dan diproduksi dari reduksi gradual molekul oksigen. Reduksi univalen oksigen menghasilkan radikal superoksid $\left(\mathrm{O}_{2} \bullet\right)$ yang sangat reaktif. Superoksid mengalami dismutasi menjadi hidrogen peroksid $\left(\mathrm{H}_{2} \mathrm{O}_{2}\right)$ oleh enzim superoksid dismutase (SOD). Pada jaringan biologik, superoksid juga dapat mengalami perubahan menjadi $\mathrm{H}_{2} \mathrm{O}_{2}$ dan oksigen singlet $\left({ }^{1} \mathrm{O}_{2}\right)$. Hidrogen peroksida dapat bereaksi dengan radikal yang lain seperti metal transisi $\mathrm{Fe}^{2+}$ (reaksi Fenton) membentuk radikal hidroksil $(\mathrm{OH} \bullet$ ) yang sangat reaktif. Mieloperoksidase, suatu protein heme dapat mengubah $\mathrm{H}_{2} \mathrm{O}_{2}$ menjadi asam hipoklorid $(\mathrm{HOCl})$ yang merupakan oksidan kuat. Asam hipoklorid dapat bereaksi dengan superoksid menghasilkan $\mathrm{OH} \bullet$. Berbagai spesies radikal dapat merusak biomolekulbiomolekul dengan cara oksidasi."1

Atom atau molekul radikal bebas sangat reaktif dan dengan mudah dapat berpartisipasi pada berbagai reaksi khemikal/biokhemikal. Suatu radikal dapat menyerang molekul nonradikal atau mengambil sebuah atom hidrogen dari ikatan $\mathrm{C}-\mathrm{H}, \mathrm{O}-\mathrm{H}$, atau S-H dari molekul nonradikal. Reaksi semacam ini sangat umum terjadi pada sistem biologik yang molekul-molekulnya kebanyakan merupakan spesies nonradikal. ROS ada yang berupa spesies radikal bebas tidak stabil (spesies khemikal yang memiliki elektron tidak berpasangan pada orbital terluarnya), seperti radikal superoksid atau radikal hidroksil, dan ada pula ROS yang berupa oksidan non radikal, seperti hidrogen peroksid (gambar 1 dan tabel 1).

\section{ROS Vaskuler}

ROS pada dinding vaskuler diproduksi secara enzimatik dan nonenzimatik oleh sel-sel vaskuler fagositik (neutrofil, monosit, makrofag) dan nonfagositik seperti endotel, SMC, dan fibroblas. ${ }^{3}$ Sel-sel fagositik inflamatorik seperti netrofil dan makrofag, bila teraktivasi akan memproduksi ROS dalam jumlah besar. Produksi ROS yang masif pada lingkungan inflamatorik ini (disebut oxidative burst) berperan penting sebagai mekanisme pertahanan pertama terhadap patogen enviromental. Sedangkan pada sel-sel nonfagositik (fibroblas, endotel, SMC, miosit kardial), ROS berperan pada regulasi kaskade signaling intraselular. Fibroblas dan SMC terutama berperan pada produksi superoksid pada kondisi vaskuler normal. Kecepatan produksi superoksid oleh sel-sel nonfagositik hanya sepertiganya dibanding netrofil. Berbeda dengan netrofil, endotel atau fibroblas, SMC terutama memproduksi superoksid dan $\mathrm{H}_{2} \mathrm{O}_{2}$ intraselular. ${ }^{3}$

Pada sel-sel vaskuler, ROS terutama diproduksi oleh beberapa sistem enzim seperti, NADPH oksidase, xantin oksidase dan uncouple nitric oxide synthase (NOS tidak terakit). Sumber ROS enzimatik yang lain adalah oksidase mitokondrial, siklooksigenase dan lipoksigenase, akan tetapi, kontribusi dan relevansi klinis dari sumber-sumber ROS ini pada dinding vaskuler belum sepenuhnya diketahui. 1.5.6 ROS juga dapat diproduksi secara non enzimatik oleh reaksi-reaksi senyawa redoks aktif seperti semiubiquinone pada rantai pengangkutan elektron pada mitokondria.

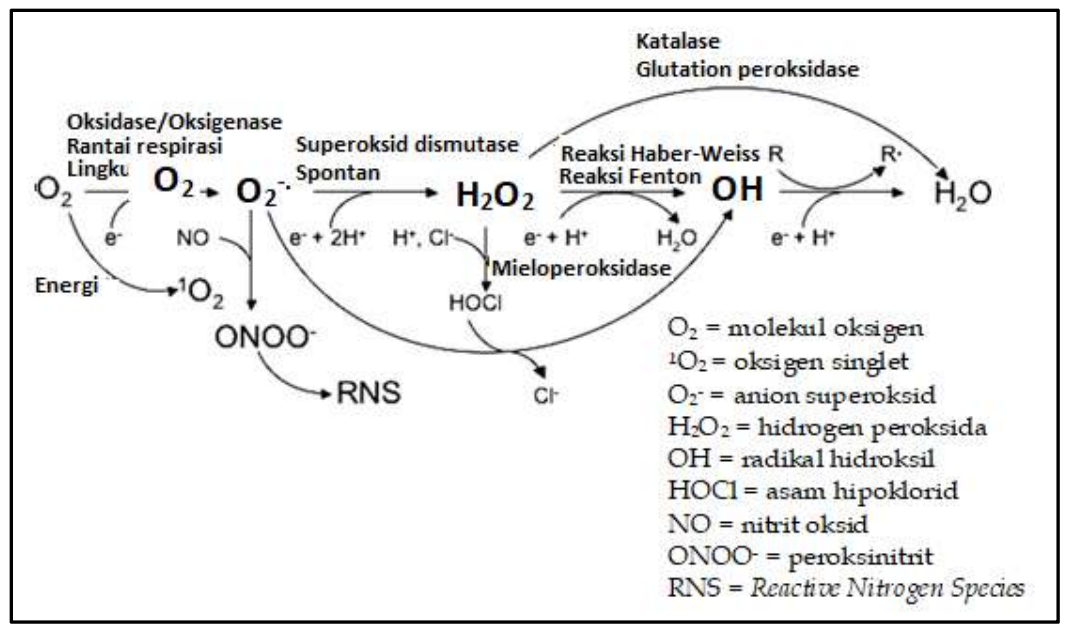

Gambar 1. Metabolisme ROS.8 
Tabel 1. Berbagai ROS jenis radikal dan non radikal. ${ }^{12}$

\begin{tabular}{|c|c|c|}
\hline \multicolumn{3}{|l|}{ Radikal } \\
\hline Superoksid & $\mathrm{O}_{2} \cdot$ & $\begin{array}{l}\text { Radikal superoksid, merupakan radikal oksigen yang utama, memiliki } \\
\text { reaktifitas selektif. Spesies ini diproduksi oleh sejumlah sistem enzim } \\
\text { melalui reaksi-reaksi autooksidasi, dan oleh transfer elektron } \\
\text { nonezimatik yang mereduksi secara univalen molekul oksigen. SOD } \\
\text { menyebabkan dismutasi } \mathrm{O}_{2}-\text { menjadi hidrogen peroksid } \mathrm{H}_{2} \mathrm{O}_{2} \text { dan } \\
\text { oksigen } \mathrm{O}_{2} \text {. }\end{array}$ \\
\hline Hidroksil & $\mathrm{OH} \bullet$ & $\begin{array}{l}\text { Radikal yang sangat reaktif yang dapat menyerang semua molekul } \\
\text { dalam tubuh }\end{array}$ \\
\hline $\begin{array}{l}\text { Peroksil, } \\
\text { alkoksil }\end{array}$ & $\begin{array}{l}\mathrm{HO}_{2}^{\bullet} \\
\mathrm{RO}_{2}^{\bullet}\end{array}$ & $\begin{array}{l}\text { Radikal organik, sering terbentuk sebagai intermediet pada } \\
\text { penguraian peroksida lipid pada reaksi peroksidasi }\end{array}$ \\
\hline $\begin{array}{l}\text { Oksida } \\
\text { nitrogen }\end{array}$ & $\mathrm{NO} \cdot \mathrm{NO}_{2}$ & $\begin{array}{l}\text { nitric oxide dibentuk in vivo dari asam amino L-arginin. Nitrogen } \\
\text { dioksida dibentuk bila } \mathrm{NO} \text { bereaksi dengan } \mathrm{O}_{2} \text { dan ditemukan pada } \\
\text { polutan dan asap. }\end{array}$ \\
\hline \multicolumn{3}{|l|}{ Non radikal } \\
\hline $\begin{array}{l}\text { Hidrogen } \\
\text { peroksid }\end{array}$ & $\mathrm{H}_{2} \mathrm{O}_{2}$ & $\begin{array}{l}\text { Dibentuk in vivo ketika } \mathrm{O}_{2} \bullet \text { mengalami dismutasi dan juga oleh enzim- } \\
\text { enzim oksidase. Kadar tinggi } \mathrm{H}_{2} \mathrm{O}_{2} \text { dapat menyerang enzim-enzim } \\
\text { penghasil energi. } \mathrm{H}_{2} \mathrm{O}_{2} \text { juga dapat membentuk } \mathrm{OH} \bullet \text { bila ada ion } \\
\text { metal transisi }\left(\mathrm{Fe}^{2+}\right), \mathrm{O}_{2} \text { memfasilitasi reaksi ini. }\end{array}$ \\
\hline $\begin{array}{l}\text { Asam } \\
\text { hipoklorid }\end{array}$ & $\mathrm{HOCl}$ & $\begin{array}{l}\text { Oksidan kuat yang dibentuk pada neutrofil manusia pada daerah } \\
\text { inflamasi oleh reaksi enzim mieloperoksidase. Pada neutrofil, } \mathrm{HOCl} \\
\text { juga dapat bereaksi dengan } \mathrm{O}_{2} \bullet \text { menghasilkan } \mathrm{OH}^{\bullet}\end{array}$ \\
\hline Ozone & $\mathrm{O}_{3}$ & $\begin{array}{l}\text { Gas yang beracun yang dapat menyebabkan deplesi antioksidan } \\
\text { vitamin } D \text {, vitamin } E \text { dan asam urat. }\end{array}$ \\
\hline $\begin{array}{l}\text { Oksigen } \\
\text { singlet }\end{array}$ & ${ }^{1} \mathrm{O}_{2}$ & $\begin{array}{l}\text { Spin dari salah satu elektron pada orbital terluar oksigen terbalik, } \\
\text { menyebabkan hilangnya hambatan quantum mechanical spin }\end{array}$ \\
\hline
\end{tabular}

Gambar 2 merangkum sumber metabolik \& enzimatik superoksid vaskuler. Anion superoksid $\left(\mathrm{O}_{2}^{-}\right)$dibentuk oleh beberapa sumber metabolik dan enzimatik di dalam sel. NADPH oksidase terdiri dari subunit-subunit yang berada pada membran dan sitoplasma. Enzim ini aktif bila protein sitoplasmik p67 dan p47 dan protein $G$ terakit dengan NOX pada membran (gp91phox) dan p22phox. NADPH oksidase menggunakan NADH sebagai substrat. Lipoksigenase dan siklooksigenase (COX) menghasilkan ROS secara tidak langsung melalui Asam arakidonat (AA) yang dipecah oleh phospholipase A2 (PLA2) kemudian dimetabolisme oleh 5-lipoksigenase (5-LO) oleh adanya protein FLAP menghasilkan leukotrien (LTs). AA juga dimetabolisme oleh COX menghasilkan mediator-mediator inflamatori prostaglandin (PGs).

Mitokondria juga menghasilkan superoksid, ketika elektron-elektron ditransfer dari kompleks I ke kompleks IV pada respirasi normal. Xantin oksidase (XO), mengubah hipoxantin dan xantin menjadi asam urat. Ketika xantin diubah menjadi asam urat, 2 elektron didonorkan ke molibdenum (Mo), sehingga tereduksi dari Mo(VI) menjadi Mo (IV).Terakhir, endothelial nitric oxide synthase (eNOS), bila substrat atau kofaktor tidak terakit akan dihasilkan superoksid yang mudah bereaksi dengan NO. $Q$ menunjukkan coenzyme Q; C, cytochrome C; FAD, flavin adenine dinucleotide; FMN, flavin mononucleotide; $\mathrm{FE}$, heme iron; $\mathrm{BH}_{4}$, tetrahydrobiopterin. ${ }^{13}$

\section{PEMBAHASAN}

\section{NADPH oksidase}

Sistem enzim nicotinamide adenine dinucleotide phosphate (NADPH) oxidase, atau yang dikenal sebagai enzim Nox, adalah sumber superoksid utama pada sel-sel vaskuler. Sistem enzim ini terutama ditemui pada netrofil dan makrofag yang teraktivasi (menjalankan aktivitas bakterisidal). NADPH oksidase juga merupakan sumber superoksid konstitutif pada membran endotel, SMC dan fibroblas. 14,15

NADPH oksidase mengkatalisa reduksi molekul oksigen menggunakan NADPH sebagai donor elektron, dan menghasilkan radikal superoksid $\left(\mathrm{O}_{2} \bullet\right)$. Keseluruhan reaksi ditulis sebagai berikut.

$$
\mathrm{NADPH}+2 \mathrm{O}_{2} \rightarrow \mathrm{NADP}^{+}+\mathrm{H}^{+}+2 \mathrm{O}_{2} .
$$

Ambilan $\mathrm{O}_{2}$ oleh sel akan mengaktifkan kompleks enzim NADPH oksidase pada membran plasma sel. Aktivasi melibatkan migrasi komponen sitosolik ke membran plasma sehingga terakit enzim aktif. Kompleks aktif ini mengoksidasi NADPH (disediakan oleh jalur metabolisme pentose fosfat dalam sitosol) menjadi NADP+ , dua elektron digunakan untuk mereduksi $\mathrm{O}_{2}$ menjadi superoksid pada permukaan ekstraselular membran. ${ }^{16}$

Enzim NADPH oksidase merupakan kompleks molekul yang terikat membran, mengandung FAD (flavin adenin dinucleotide) dan sitokrom b558, bagian yang berperan mereduksi $\mathrm{O}_{2}$ menjadi $\mathrm{O}_{2} \bullet$. Sitokrom b558 merupakan suatu dimer, terdiri dari subunit $\beta$ (gp/phox) dan subunit a (p22phox). Subunit $\beta$ mengandung FAD dan dua heme. Pada netrofil, $30 \%$ sitokrom b558 terdapat pada 
membran plasma dan sisanya pada sitoplasma dalam granula khusus, yang dapat mensuplai sitokrom b558 ke membran plasma saat aktivasi dari respiratory burst. Aktivasi NADPH oksidase membutuhkan protein sitosolik, misalnya pada netrofil p47phox, p67phox dan mungkin p40phox. Protein-protein ini berada pada membran dan membantu aktivasi enzim. ${ }^{16}$

Enzim NADPH oksidase merupakan kompleks molekul yang terikat membran, mengandung FAD (flavin adenin dinucleotide) dan sitokrom b558, bagian yang berperan mereduksi $\mathrm{O}_{2}$ menjadi $\mathrm{O}_{2}$. . Sitokrom b558 merupakan suatu dimer, terdiri dari subunit $\beta$ (gp'phox) dan subunit a (p22phox). Subunit $\beta$ mengandung FAD dan dua heme. Pada netrofil, 30\% sitokrom b558 terdapat pada membran plasma dan sisanya pada sitoplasma dalam granula khusus, yang dapat mensuplai sitokrom b558 ke membran plasma saat aktivasi dari respiratory burst. Aktivasi NADPH oksidase membutuhkan protein sitosolik, misalnya pada netrofil p47phox, p67phox dan mungkin p40phox. Protein-protein ini berada pada membran dan membantu aktivasi enzim. ${ }^{16}$

NADPH oksidase juga mengandung protein $G$ famili rac, yang berfungsi pada transduksi signal yang mengaktifkan enzim ini. Jalur transduksi signal yang menyebabkan aktivasi enzim oksidase ini oleh stimuli fisiologikal terdiri dari, reseptor-reseptor membran, protein G, fosfolipase C (fosfatidilinositol spesifik) dan protein kinase $C$ (PKC). Hidrolisis fosfatidilinositol 4,5 difosfat menghasilkan inositol 1,2,5 trifosfat $\left(\mathrm{IP}_{3}\right)$ dan diasil gliserol. (DAG). IP 3 memasuki sitoplasma dan meningkatkan $\mathrm{Ca}^{2+}$ bebas intraselular, sedangkan DAG berperan mengaktifkan PKC, menyebabkan fosforilasi berbagai protein, termasuk p47phox .Fosforilasi ini meningkatkan translokasi elektron ke membran dan menyebabkan aktifnya enzim. Jadi, NADPH oksidase menjadi aktif bila terdapat translokasi elektron dari molekul sitosolik $\mathrm{p}^{47}, \mathrm{p}^{67}$ dan protein $G$, ke kompleks molekul sitokrom b588 pada membran. 3,16

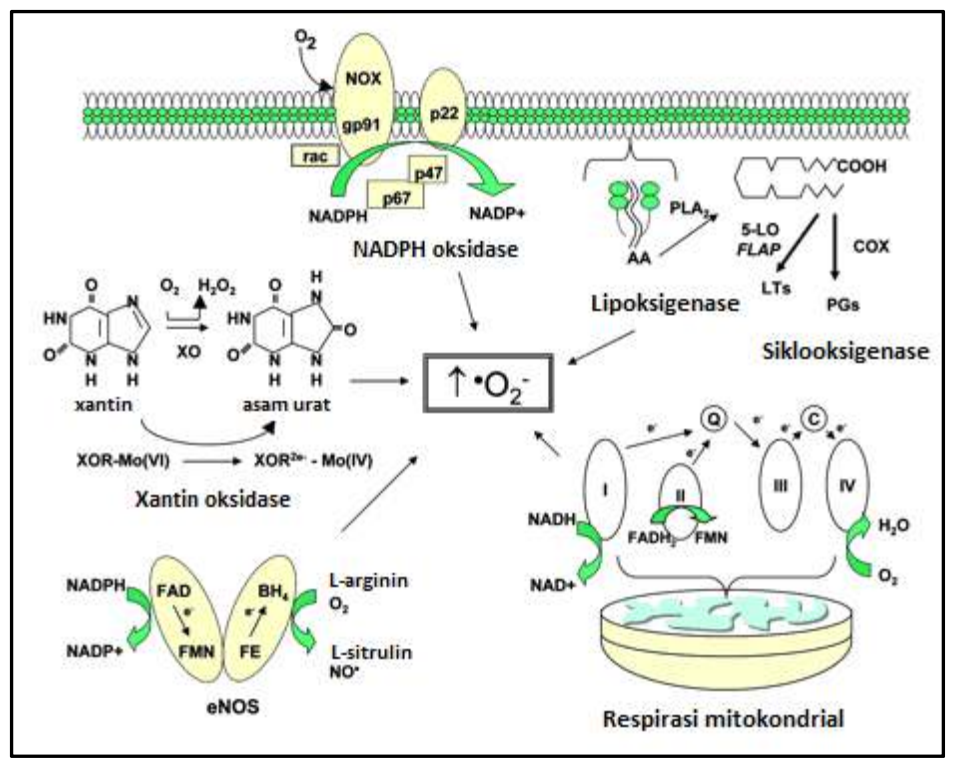

Gambar 2. Sumber metabolik \& enzimatik superoksid vaskuler..$^{13}$

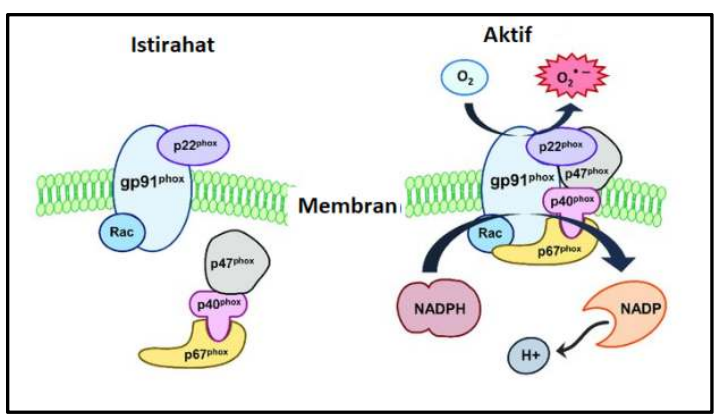

Gambar 3. Aktivasi NADPH oksidase ${ }^{16}$

NADPH oksidase pada sel-sel vaskuler, aktif secara konstitutif dan memproduksi ROS dalam jumlah kecil pada kondisi basal. Akan tetapi, NADPH oksidase akan memproduksi 
ROS dalam jumlah besar bila merespon stimuli growth factor (PDGF, platelet-derived growth factor), produk-produk bakterial seperti LPS (liposakarida) dan lipoprotein, atau oleh stimuli sitokin seperti interferon- $\gamma$ (IFN- $\gamma$ ), interleukin-1 $\beta$ (IL-1 $\beta$ ), tumor necrosis factor (TNF-a) atau IL-8. Faktor-faktor lain juga dapat menginduksi aktivitas NADPH oksidase diantaranya, faktor hemodinamik, perubahan metabolik, trombin, angitensin II, dan beberapa hormon. ${ }^{3}$

Beberapa peneliti menyebut subunit katalitik NADPH oksidase sebagai protein Nox. Komponen protein (Nox) NADPH oksidase pada sel-sel vaskuler berbeda-beda. Fibroblast dan endotel seperti pada fagosit mengandung mRNA untuk gp91phox, p22phox, p47phox, and p67phox, sedangkan pada SMC tidak ada gp9lphox dan gp67phox. Sebagai gantinya, sel-sel ini mengandung protein homolog gp91phox. Nox1, -4, dan -5 telah diidentifikasi pada sel-sel vaskuler. Endotel mengekspresikan sangat sedikit Noxl, agak banyak Nox2, dan banyak Nox4. Sebaliknya, SMC terutama mengekspresikan Nox4 dan sedikit Noxl, sedang Nox2 hampir tidak ditemui. Pada pembuluh tertentu ekspresi Nox berbeda, Nox2 relatif banyak pada SMC aorta manusia. Selain itu kini diketahui bahwa Noxl dan Nox4 terletak pada kompartemen sel yang berbeda. ${ }^{17}$

\section{Xantin oksidase}

Xantin oksidase $(\mathrm{XO})$ adalah anggota famili molibdoenzim yang mengkatalisis tahap akhir degradasi purin, yaitu transformasi hipoxantin dan xantin menjadi asam urat. Reaksi $X O$ juga menghasilkan produk samping berupa ROS, yaitu radikal superoksid, yang kemudian diubah menjadi hidrogen
$\begin{gathered}\text { peroksida. }{ }^{18,19} \\ \text { Xantin oksidase merupakan isoform }\end{gathered}$ Xantin oksidoreduktase (XOR). Terdapat dua isoform XOR yaitu xantin dehidrogenase (XDH) dan xantin oksidase (XO), masing-masing menggunakan aseptor elektron yang berbeda. XDH menggunakan $\mathrm{NAD}^{+}$sebagai aseptor elektron dari hipoxantin dan xantin, menghasilkan NADH dan asam urat. Sebaliknya XO menggunakan oksigen sebagai penerima elektron dari substrat yang sama, menghasilkan radikal superoksid dan hidrogen peroksida. Karenanya, rasio XO terhadap XDH dalam sel menentukan jumlah ROS yang diproduksi enzim ini.

Enzim XOR merupakan suatu homodimer yang masing-masing terdiri dari, subunit katalitik indipenden dengan berat molekul mendekati $150 \mathrm{kDa}$, memiliki satu gugus molibdenum, dua gugus iron-sulfur, dan satu FAD. Tiap-tiap subunit terorganisasi menjadi tiga domain yaitu, 1) domain $\mathrm{N}$-terminal (asam amino 1-165) mengandung gugus iron-sulfur, 2) domain intermediet (asam amino 226 - 531) mengandung FAD, dan 3) domain C-terminal (asam amino 590-1332) merupakan domain terbesar yang mengandung molibdenum. ${ }^{21}$

XDH dapat berubah menjadi XO secara nonreversibel karena serangan proteolitik (tripsin, khimotripsin, atau pankreatin), atau secara reversibel karena oksidasi gugus tiol pada Cys535 and Cys992 (misalnya karena penyimpanan pada at $-20^{\circ} \mathrm{C}$, inkubasi pada $37^{\circ} \mathrm{C}$, paparan terhadap bahan mengandung sulfidril atau kondisi anaerobik). Stimuli yang menyebabkan perubahan XDH menjadi XO diantaranya TNF-a dan peroksinitrit.3,21

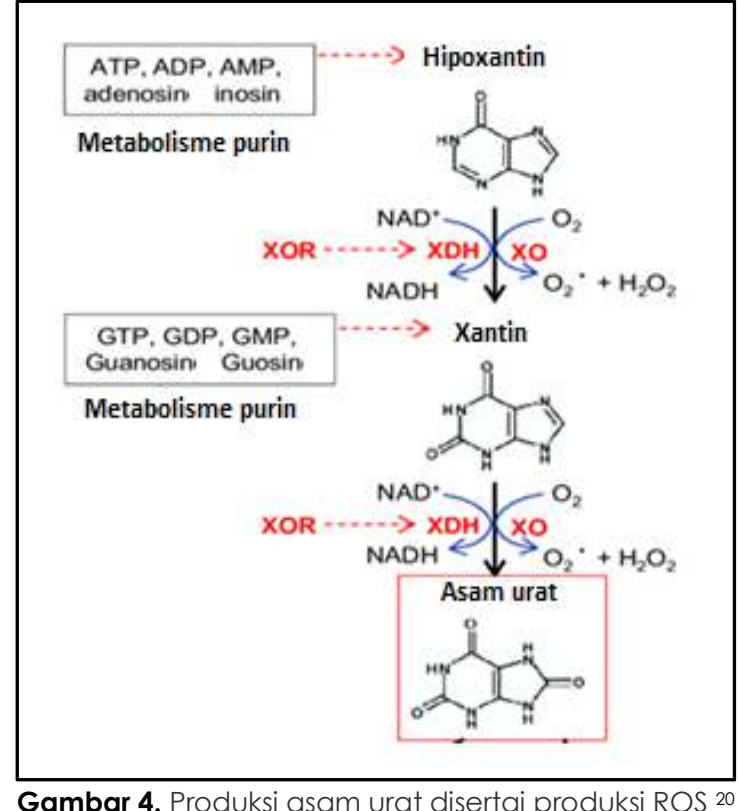




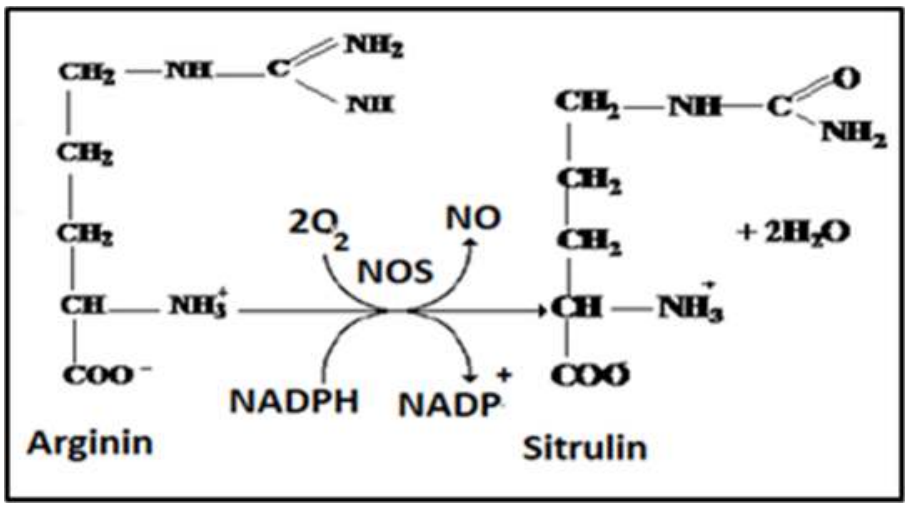

Gambar 5. Peran NOS pada

pembentukan NO. ${ }^{23}$

Penelitian biokimia, molekular dan farmakologi menunjukkan XOR merupakan sumber ROS pada sistem kardiovaskular. ${ }^{21}$ Namun demikian, masih menjadi perdebatan, apakah XDH diekspresikan. Studi-studi histokimia pada jaringan manusia yang normal tidak dapat menunjukkan adanya ekspresi XDH pada sel-sel endotelial atau jaringan kardiovaskuler yang lain. Sebaliknya bisa ditunjukkan bahwa $\mathrm{XO}$ dapat menghasilkan ROS yang mempengaruhi fungsi patologik endotel manusia. XO ditemukan pada sel-sel plasma dan endothelial, tetapi tidak ditemukan pada SMC.

Stimulasi ekspresi $\mathrm{XO}$ dapat disebabkan oleh sitokin-sitokin inflamatorik atau oleh stimuli lain. Misalnya Sohn dkk. Telah menunjukkan bahwa hipoksia menginduksi aktivitas $\mathrm{XO}$ pada human umbilical vein endothelial cells. Ada konsep menarik yang menyebutkan bahwa XO pada endotel berasal dari organ lain, dan XO mungkin diambil oleh endotel melalui heparin binding sites. Tanpa memperhatikan dari mana asalnya, yang jelas aktivitas vaskuler $\mathrm{XO}$ berbanding terbalik dengan fungsi endotel pada pasien gagal jantung dan aterosklerosis.

Telah lebih dari 35 tahun berlalu sejak ditemukan, XOR dianggap sebagai sumber ROS pada iskemia/injuri reperfusi. Sejak itu, berbagai penyakit inflamatori dihubungkan dengan peningkatan XOR dan pembentukan ROS. Hal ini memperkuat pendapat bahwa adanya peningkatan XOR berarti akan menyebabkan memburuknya kondisi klinis. Tetapi, bukti-bukti terbaru mengubah paradigma tersebut, dengan adanya penjelasan tentang kapasitas XOR sebagai reduktase nitrat/nitrit, diduga XOR bermanfaat sebagai sumber NO pada kondisi iskemia/hipoksia/asidik, ini sama halnya dengan membatasi kapasitas fungsional NO sintase. Dalam artikelnya Cantu-Medellin dkk (2013) mendefinisikan kembali dogma yang ada dan menyampaikan hal baru bahwa XOR bukan memberi dampak negatif, melainkan merupakan komponen penting dari pemeliharaan homeostasis. 22

Uncoupled endothelial Nitric Oxide Synthase
Kontributor ketiga sumber ROS vaskuler adalah enzim NOS yang tidak terakit (uncouple endothelial nitric oxide synthase). NOS, adalah enzim yang berperan pada pembentukan NO (nitric oxide), Enzim NOS memiliki tiga isoform yaitu, NOS1 (neural NOS), NOS2 (inducible NOS, iNOS), dan NOS3 (endothelial NOS, eNOS). Pada dinding vaskuler, NO diproduksi oleh endothelium melalui ekspresi konstitutif eNOS, yang diaktifkan shear-stress dan stimulasi agonis seperti bradikini dan asetilkholin. 23

Pada kondisi fisiologik, NOS mengkatalisis perubahan arginin menjadi sitrulin dan NO, menggunakan kofaktor $\mathrm{Ca}^{2+} /$ calmodulin, NADPH, FAD, FMN (flavin mononukleotid), dan 5,6,7,8-tetrahydrobiopterin (BH4). Mekanisme katalitik NOS melibatkan transport elektron yang dimediasi oleh flavin dari gugus Cterminal (terikat NADPH) ke heme, yang kemudian mereduksi oksigen dan berikatan dengan gugus guanidin pada L-arginin, menghasilkan NO dan L-citrulline. 23,24 Bila enzim ini kekurangan $\mathrm{BH} 4$, eNOS tidak terakit secara normal (uncoupled), aliran elektron dari domain reduktase ke heme cenderung menuju ke molekul oksigen dari pada ke Larginin, sehingga diproduksi radikal superoksid. Perlu diingat bahwa uncoupled eNOS tidak terjadi secara keseluruhan, artinya tetap ada eNOS yang menghasilkan NO. Sehingga pada kondisi kekurangan $\mathrm{BH} 4$, eNOS memproduksi superoksid dan NO. Selanjutnya, superoksid mudah bereaksi dengan NO membentuk peroxynitrite (ONOO-suatu RNS, reactive nitrogen species) yang memiliki efek merusak melalui mekanisme oksidasi, nitrasasi dan nitrosasi. ${ }^{24,25}$

Kadar $\mathrm{BH} 4$ jaringan ditentukan oleh keseimbangan antara produksi dan degradasinya. BH4 disintesis dari GTP (guanosin triphosphat) melalui jalur de novo oleh enzim 5'-triphosphate (GTP) cyclohydrolase I (GTPCH I). Alternatifnya, sintesis $\mathrm{BH} 4$ dapat terjadi melalui jalur salvage, yang menggunakan $\mathrm{BH} 2$ sebagai substrat. Karenanya, berkurangnya aktivitas GTPCH I menghasilkan penurunan kadar $\mathrm{BH} 4$ dalam jaringan. ${ }^{26}$

Gambar 6 menunjukkan skema hipotetikal peran eNOS pada aterogenesis. 
Pada kondisi fisiologik, kadar BH4 optimal untuk aktivitas katalitik eNOS, dan aktivasinya menghasilkan NO dan L-citrulline. NO yang dihasilkan eNOS berfungsi sebagai molekul anti-aterogenik. Pada hiperkolesterolemia dan aterosklerosis, stres oksidatif meningkat, kadar
$\mathrm{BH} 4$ dalam jaringan menurun. Kekurangan $\mathrm{BH} 4$ ini menyebabkan tidak terakitnya eNOS sehingga lebih banyak dihasilkan superoksid dari pada NO. Selanjutnya superoksid, peroksinitrit dan $\mathrm{H}_{2} \mathrm{O}_{2}$ menyebabkan kerusakan endotel dan berperan pada aterosklerosis. ${ }^{2}$

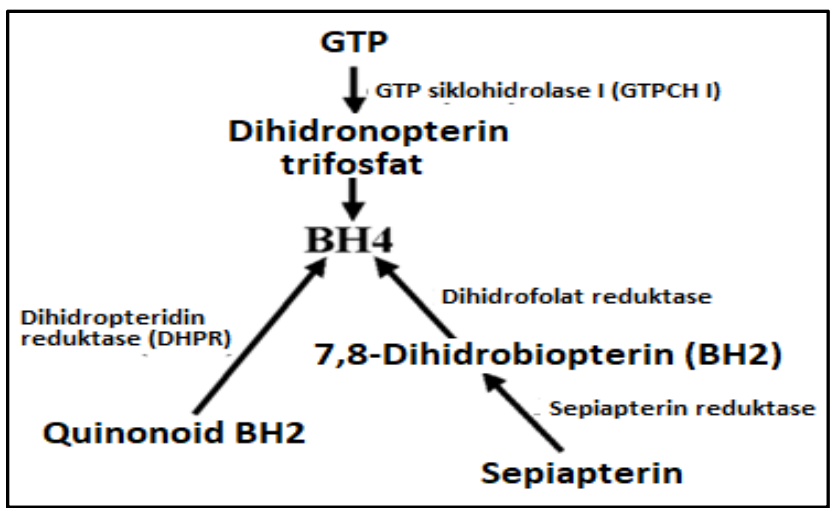

Gambar 6. Skema biosintesis BH4. ${ }^{26}$

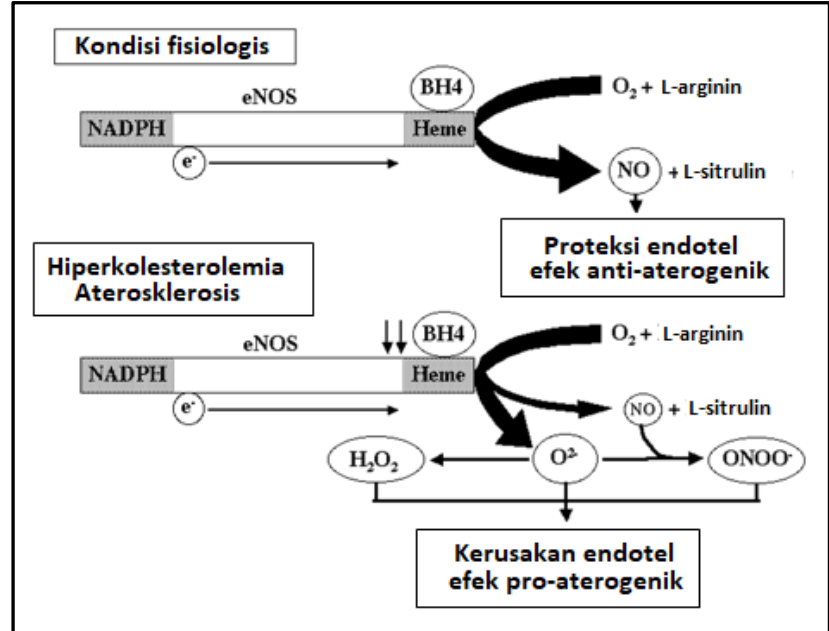

Gambar 7. Skema hipotetikal peran eNOS pada aterogenesis. ${ }^{2}$

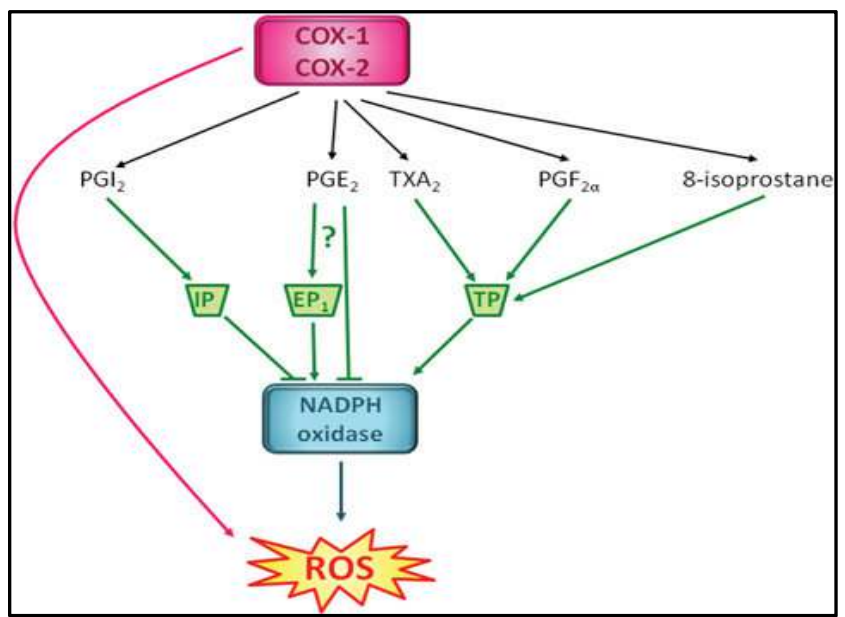

Gambar 8. Efek produk-produk COX pada produksi ROS. ${ }^{28}$ 


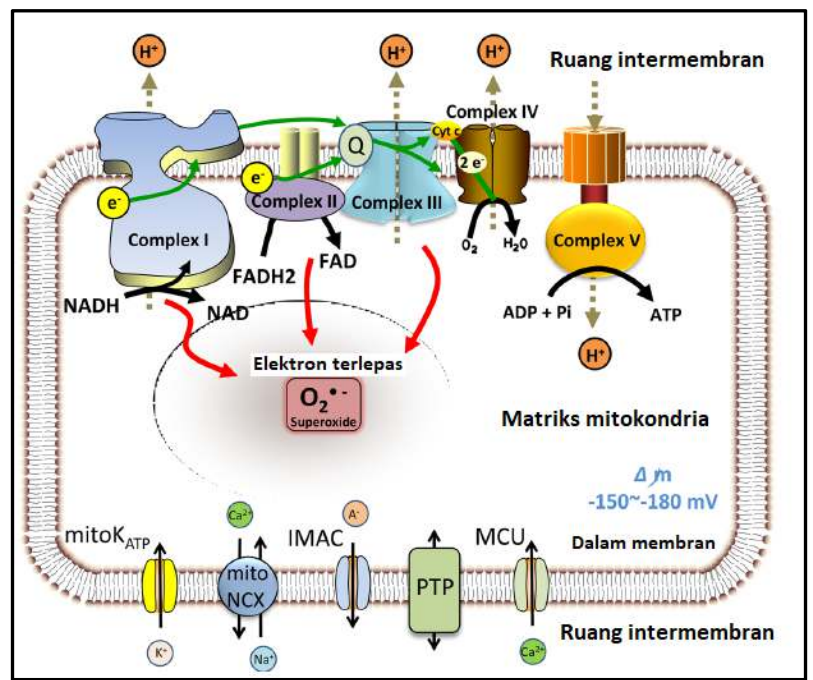

Gambar 9. Fosforilasi oksidatif dan produksi ROS dalam mitokondria. ${ }^{6}$

\section{Siklooksigenase dan lipoksigenase}

ROS juga dihasilkan dari metabolisme oksidatif pemecahan asam arakidonat (AA), melalui jalur metabolisme siklooksigenase (COX) dan Lipoksigenase (LOX). Asam arakidonat dihasilkan dari pemecahan fosfolipid membran sel oleh enzim phospholipase A2 (PLA2), AA kemudian dimetabolisme oleh 5-lipoksigenase (5-LO) oleh adanya protein FLAP menghasilkan leukotrien (LTs). AA juga dimetabolisme oleh COX menghasilkan mediator-mediator inflamatori prostaglandin (PGs). ${ }^{28}$ Akhir-akhir ini, bukti-bukti yang berkembang menunjukkan bahwa pembentukan metabolit-metabolit AA (terkait aktivitas LOX dan COX) dapat menginduksi pembentukan ROS dengan menstimuli NADPH oxidase (NOX) dan diduga ada koneksi signaling antara metabolitmetabolit LOX/COX dengan NOX.28 Pada gambar 8 ditunjukkan Efek produk-produk COX pada produksi ROS. ${ }^{28}$ Berbagai jenis prostanoid memodulasi produksi ROS melalui peningkatan aktivitas NADPH oksidase. Selain itu, aktivitas COX dapat memproduksi ROS.

\section{Rantai Respirasi Mitokondrial.}

Dalam mitokondria, ROS diproduksi sebagai produk samping yang tak terhindarkan pada proses fosforilasi oksidasi akibat terlepasnya secara dini electron selama proses pengangkutannya ke molekul oksigen. Diperkirakan terdapat $0,1 \%-1 \%$ elektron terlepas secara prematur sehingga terbentuk ROS.

Mitokondria berperan menyediakan energi (ATP) bagi sel melalui mekanisme fosforilasi oksidatif (pembentukan ATP dari fosforilasi ADP). Energi yang digunakan pada fosforilasi oksidatif berasal dari rantai pengangkutan elektron (electron transport chain, ETC) atau disebut juga rantai respirasi). Pada rantai respirasi, elektron ditransfer dari
NADH atau FADH2 (dihasilkan oleh siklus Krebs) ke molekul oksigen, dan menyebabkan reduksi oksigen (oksigen sebagai aseptor elektron tahap akhir) menjadi $\mathrm{H}_{2} \mathrm{O}$ (reduksi sempurna membutuhkan 4 elektron).

Rantai pengangkutan elektron melibatkan molekul-molekul pembawa elektron yang terletak pada membran dalam mitokondria meliputi, molekul kompleks I (NADH-ubiquinon oksidoreduktase), kompleks II (suksinat-ubiquinon oksidoreduktase), kompleks III (ubiquinol-sitokrom C reduktase), dan kompleks IV (sitokrom C oksidase). Kira-kira 98\% elektron yang ditransfer oleh molekulmolekul karier tersebut digunakan untuk fosforilasi ADP menghasilkan ATP. Terdapat $1 \%$ $-2 \%$ elektron tercecer (sumber lain menyebutkan $0,1 \%$ - $1 \%$ ) sehingga dihasilkan intermediet radikal bebas (ROS)."

Urutan donasi elektron dari NADH/FADH2 ke oksigen pada rantai respirasi dapat menghasilkan ROS sebagai intermediatnya. Donasi satu elektron ke molekul oksigen menghasilkan radikal superoksid $\left(\mathrm{O}_{2} \cdot-\right)$. Donasi elektron kedua menghasilkan $\mathrm{H}_{2} \mathrm{O}_{2}$. Donasi elektron ketiga seperti yang terjadi pada reaksi Fenton $\left(\mathrm{Fe}^{2+}+\mathrm{H}_{2} \mathrm{O}_{2} \rightarrow \mathrm{Fe}^{3+}+\cdot \mathrm{OH}+\mathrm{OH}^{-}\right)$ menghasilkan radikal hidroksil $(\cdot \mathrm{OH})$ yang sangat reaktif. Donasi elektron keempat menghasilkan $\mathrm{H}_{2} \mathrm{O}$. Selain itu dapat juga terbentuk oksigen singlet $\left({ }^{\prime} \mathrm{O}_{2}\right)$, suatu bentuk molekul oksigen yang sangat pendek umurnya, elektron terluarnya berpindah ke tingkatan energi yang lebih tinggi. Oksigen singlet dapat dibentuk oleh berbagai mekanisme misalnya melalui reaksi HaberWeiss $\left(\mathrm{H}_{2} \mathrm{O}_{2}+\mathrm{O}_{2} \cdot-\cdot \rightarrow \cdot \mathrm{OH}+\mathrm{OH}^{-}+{ }^{1} \mathrm{O}_{2}\right) .{ }^{29}$ Pada organ dan jaringan lain (selain vaskuler), rantai respirasi pada mitokondria merupakan sumber utama spesies radikal dan $\mathrm{H}_{2} \mathrm{O}_{2}$. Diperkirakan antara $1 \%-2 \%$ oksigen yang bereaksi tidak direduksi secara sempurna sehingga menghasilkan radikal. ${ }^{24}$ 
Pada dinding vaskuler, kontribusi yang pasti dari ROS mitokondrial pada total produksi ROS, masih belum jelas. Sebagian dari problem ini berkaitan dengan kenyataan belum ditemukannya antagonis yang spesifik. Misalnya rotenon yang sering digunakan untuk menghambat produksi radikal mitokondrial ternyata mempunyai efek yang sebaliknya. Selain itu, inhibisi fungsi mitokondria dapat secara dramatis mengubah aspek metabolisme sel yang lain, sehingga hasil dari suatu intervensi sulit diinterpretasikan.

Diagram skematik fosforilasi oksidatif dan produksi ROS dalam mitokondria ditunjukkan pada Gambar 8. Pada diagram membran dalam mitokondria menunjukkan komponenkomponen kunci rantai pengangkutan electron (electron transport chain, ETC), dan kanal serta transporter. NADH dan FADH yang diproduksi dari Siklus Krebs (Tricarboxylic acids, TCA) memberikan electron pada ETC di sepanjang membrane dalam mitokondria. Elektron mengalir melewati ETC dengan urutan sebagai berikut: Kompleks I dan II $\rightarrow$ Koenzim $Q$ $[Q] \rightarrow$ Kompleks III--? Sitokrom C [Cy† C] $\rightarrow$ kompleks IV $\rightarrow \mathrm{O}_{2}$, pada saat ini terjadi reaksi redoks yang mendorong $\mathrm{H}^{+}$melintasi membrane dalam, menghasilkan gradient proton dan potensial membrane mitokondria bermuatan negative. Energi bebas yang tersimpan dalam gradient proton kemudian mendorong $\mathrm{H}+$ menuju ATP Sintase (Kompleks V), mengubah ADP menjadi ATP. Diperkirakan $0,1 \%-1 \%$ electron terlepas secara prematur yaitu pada Kompleks I, II, atau III menghasilkan terbentuknya superoxide $\left(\mathrm{O}_{2} \cdot-\right)^{-6}$

Sel-sel vaskuler fagositik seperti netrofil, monosit/makrofag merupakan sumber utama ROS vaskuler. Sumber-sumber ROS vaskuler utama meliputi, NADPH oksidase, xantin oksidase, eNOS, lipoksigenase, siklooksigenase dan sistem transpor elektron mitokondrial. Adanya jejas/stimuli vaskuler akan menstimuli produksi ROS dalam jumlah yang besar dari selsel tersebut.

Infeksi mikroorganisme (bakteri, virus, jamur, parasit, dan lain-lain) akan menginduksi respon inflamasi vaskuler yang menghasilkan peningkatan produksi ROS yang masif dan menyebabkan kerusakan vaskuler. Prevalensi penyakit infeksi di Indonesia cukup tinggi, barangkali ini berkorelasi positif dengan prevalensi penyakit kardiovaskuler, diperlukan penelitian-penelitian lebih lanjut untuk mengungkap hal ini. Selain itu, Semakin difahaminya peran oksidan/ROS, membuka peluang untuk mengembangkan penelitian untuk pencegahan dan terapi penyakit kardiovaskuler berbasis antioksidan.

\section{Daftar Singkatan}

eNOS= endothelial nitric oxide synthase, $\mathrm{NADPH}=$ nicotinamide adenine dinucleotide phosphate (reduced), ROS = reactive oxygen species, SMC= smooth muscle cell

\section{DAFTAR PUSTAKA}

1. Panth N, Paudel KR, and Parajuli K. Reactive Oxygen Species: A Key Hallmark of Cardiovascular Disease. Hindawi Publishing Corporation Advances in Medicine. 2016. http://dx.doi.org/10.1155/2016/9152732

2. Lushchak V. Free radicals, reactive oxygen species, oxidative stresses and their classifications. The Ukrainian Biochemical Journal. 2015; 87(6):11-18. DOI: 10.15407/ubj87.06.01 1

3. Lobo V, Patil A, Phatak A, and Chandra $N$. Free radicals, antioxidants and functional foods: Impact on human health. Pharmacogn Rev. 2010; 4(8): 118 126. doi: $10.4103 / 0973-7847.70902$

4. Kyaw Toledo-lbelles $\mathrm{P}$ and Mas-Oliva J. Antioxidants in the Fight Against Atherosclerosis: Is This a Dead End? Current Atherosclerosis Reports. 2018; 20: 36. https://doi.org/10.1007/s1 1883-018$\underline{0737-7}$

5. Chen $Q$, Wang $Q$, Zhu J, Xiao $Q$ and Zhang L. Reactive oxygen species: key regulators in vascular health and diseases. British Journal of Pharmacology. 2018;175: 1279-92.

6. Yang KC, Kyle JW, Makielski JC, Dudley Jr SC. Mechanisms of Sudden Cardiac Death Oxidants and Metabolism. Circ Res. 2015;116:1937-55. DOI: 10.1161/CIRCRESAHA. 116.304691.

7. Gracia KC, Llanas-Cornejo D, and Husi H. CVD and Oxidative Stress. J Clin Med. 2017; 6(2): 22. doi: 10.3390/jcm6020022.

8. Szasz T., Thakali K., Fink GD. And Watts SW. 2007. A Comparation of Arteries and Veins in Oxidative Stress: Procedurs, Destroyers, Function, and Disease. Experimental Biology and Medicine. 2007; 232:27-37.

9. Yang $X$, Yang Li, Li Y, Ren $X$, Zhang $X$, Hu D, Gao $Y$, Xing $Y$, and Shang $H$. Oxidative Stress-Mediated Atherosclerosis: Mechanisms and Therapies. Front Physiol. 2017; 600. doi: $10.3389 /$ fphys. 2017.00600

10. Nedeljkovic ZS., Gokce N and Loscalzo J. Mechanisms of Oxidative Stress and Vascular Disfunction. Postgraduate Medical Journal. 2003; 79:195-200.

11. Madamanchi NR., Vendrov A., Runge MS. Oxidative Stress and Vascular Disease. . Arteriosclerosis, Thrombosis, and Vascular Biology. 2005; 25(1):29-38.

12. Griendling KK, Touyz RM, Zweier JL, Dikalov S, Chilian W, Chen YR, Harrison DG, and Bhatnagar A. Measurement of Reactive Oxygen Species, Reactive Nitrogen Species, and Redox-Dependent Signaling in the Cardiovascular System. A 
Scientific Statement From the American Heart Association. Circulation Research. 2016; 119:39-75 https://doi.org/10.1161/RES.00000000000 00110.

13. Leopold JA., Loscalzo J. 2005. Oxidative Enzymopathies and Vascular Disease. ArterioscleRosis, Thrombosis, and Vascular Biology. 2005; 25:1332.

14. Camargo LL, Harvey AP, Rios FJ, Tsiropoulou S, Silva RDNOD, Cao Z, Graham D, McMaster C, Burchmore RJ, Hartley RC, Bulleid N, Montezano AC, Touyz RM. Vascular Nox (NADPH Oxidase) Compartmentalization, Protein Hyperoxidation, and Endoplasmic Reticulum Stress Response in Hypertension. Hypertension. 2018; 72(1): 235-46.

15. Altenhofer S, Kleikers PW, Radermacher KA, Scheurer P, Rob Hermans JJ, Schiffers $\mathrm{P}, \mathrm{Ho} \mathrm{H}$, Wingler $\mathrm{K}$, and Schmidt $\mathrm{HH}$. The NOX toolbox: validating the role of NADPH oxidases in physiology and disease. Cell Mol Life Sci. 2012; 69: 232743. doi: 10.1007/s00018-012-1010-9

16. Kim JY, Park J, Lee JE and Yenari MA . NOX Inhibitors - A Promising Avenue for Ischemic Stroke. Exp Neurobiol. 2017; 26(4):195-205.

https://doi.org/10.5607/en.2017.26.4.19

17. Adwas AA, Elsayed ASI, Azab AE, et al. Oxidative stress and antioxidant mechanisms in human body. J Appl Biotechnol Bioeng. 2019; 6(1):43-7. DOI: 10.15406/jabb.2019.06.00173

18. Battelli MG, Polito L, Bortolotti $M$, Bolognesi A. Xanthine OxidoreductaseDerived Reactive Species: Physiological and Pathological Effects. Oxid Med Cell Longev. 2016: 3527579.

19. Battelli MG, Polito L, Bortolotti $M$, Bolognesi A. Xanthine Oxidoreductase in Drug Metabolism: Beyond a Role as a Detoxifying Enzyme. Curr Med Chem. 2016; 23(35): 4027-36.

20. Chen C, LÜ JM, Yao Q. HyperuricemiaRelated Diseases and Xanthine Oxidoreductase (XOR) Inhibitors: An
Overview. Medical Science Monitor: International Medical Journal of Experimental and Clinical Research. 2016; 22: 2501-12. DOI:10.12659/MSM.899852

21. Battelli MG, Polito L, Bolognesi A. Xanthine oxidoreductase in atherosclerosis pathogenesis: Not only oxidative stress. Atherosclerosis. 2014; 237(2):562-7. https://doi.org/10.1016/j.atherosclerosis.2 014.10 .006

22. Cantu-Medellin N and Kelley EE. Xanthine oxidoreductase-catalyzed reactive species generation: A process in critical need of reevaluation Redox Biol. 2013; 1(1): 353doi: 10.1016/j.redox.2013.05.002

23. Ozcan A and Ogun M. Basic Principles and Clinical Significance of Oxidative Stress Chapter 3: Biochemistry of Reactive Oxygen and Nitrogen Species. Open access peer-reviewed. 2015. doi.org/10.5772/61193

24. Muller C., Laude K., McNally S., Harrison DG. Redox Mechanism in Blood Vesel. . Arteriosclerosis, Thrombosis, and Vascular Biology. 2005; 25(2): 274.

25. Senoner T and Dichtl W. Oxidative Stress in Cardiovascular Diseases: Still a Therapeutic Target? .Nutrients. 2019; 11 : 2090; doi:10.3390/nu 11092090

26. Daiber A, Xia N, Steven S, Oelze M, Hanf A, Kröller-Schön S, Münzel T and Huige L. New Therapeutic Implications of Endothelial Nitric Oxide Synthase (eNOS) Function/Dysfunction in Cardiovascular Disease. Int. J. Mol. Sci. 2019, 20: 187. doi:10.3390/ijms20010187

27. Hernanz R, Briones $A M$, Salaices $M$ and Alonso M. New roles for old pathways? A circuitous relationship between reactive oxygen species and cyclo-oxygenase in hypertension. Clinical Science. 2014; 126: 111-21. doi: 10.1042/CS20120651

28. Giordino FJ. 2005. Oxygen, Oxidative Stress, Hypoxia and Heart Failure. J. Clint. Invest. 2005; 1 15: 500-8 